\title{
Biologic Therapies and Autoimmune Phenomena
}

\section{Alexandros A. Drosos (iD, Eleftherios Pelechas (D), Evripidis Kaltsonoudis (D), Theodora E. Markatseli (iD, Paraskevi V. Voulgari}

Rheumatology Clinic, Department of Internal Medicine, Medical School, University of Ioannina, loannina, Greece

\section{ABSTRACT}

The use of biologic medications has represented a great advancement in the treatment of autoimmune rheumatic diseases. Despite their excellent efficacy, during the last years, a growing number of reports of autoimmune phenomena and paradoxical inflammation has emerged. These phenomena may range from the discovery of an isolated autoantibody to full-blown autoimmune diseases, organspecific and systemic. This review has been carried out in order to underline the multitude of the potential adverse manifestations from the use of biologic medications. Thus, early recognition of specific types of autoimmune phenomena is an imperative for the physicians allowing them to have an accurate diagnosis and treatment.

Mediterr J Rheumatol 2021;32(2):96-103

https://doi.org/10.31138/mjr.32.2.96

Article Submitted: 20 Dec 2020; Article Accepted: 20 Apr 2021; Available Online: 30 Jun 2021

Keywords: Biologic agents, autoimmune phenomena, paradoxical inflammation, adverse events, treatment

\section{INTRODUCTION}

Our immune system has evolved over millions of years, and has developed well-organized and sophisticated defence mechanisms to protect the host against infections, or cancer while maintaining homeostasis through negative regulation of cell activation. The principal cells of immune system are $\mathrm{T}$ and $\mathrm{B}$ lymphocytes, antigen presenting cells, and effector cells. These cells are concentrated in anatomical discreet sites which are called lymphoid

\section{Corresponding Author:}

Alexandros A. Drosos

Rheumatology Clinic, Department of

Internal Medicine

Medical School, University of loannina

loannina 45110, Greece

Tel: +30 2651007503

Fax: +302651007054

E-mail: adrosos@uoi.gr;

www.rheumatology.gr organs, and are also present in the peripheral blood. The cells of the immune system interact with one another and host cells through soluble mediators (proteins), produced by various cells, named cytokines. ${ }^{1}$ Autoim- mune rheumatic diseases (ARD) are characterized by dysregulation of the immune system with aberrant activation of lymphocytes and macrophages in the target organs, as well as increased production of pro-inflammatory cytokines like tumour necrosis factor a (TNFa), interleukin (IL)-1, IL-6, IL-17, interferons a, $\beta$ (INF), which are found in the tissue of inflammation and in peripheral blood. ${ }^{2}$ To this end, during the last two decades, biologic agents targeting cytokines or $\mathrm{T}$ and $\mathrm{B}$ cells have been developed and used for the treatment of ARDs, which have revolutionised the management of these disorders. ${ }^{3}$ Biological drugs targeting compounds of the immune system have been used for the treatment of rheumatoid arthritis (RA), psoriasis, psoriatic arthritis (PsA), ankylosing spondylitis (AS), inflammatory bowel diseases (IBD), systemic lupus erythematosus (SLE), and vasculitis. ${ }^{4}$

However, by blocking the cytokines or lymphocytes of the immune system, adverse events may occur. Among them mycobacterial, bacterial, viral or other infections have been reported, ${ }^{5,6}$ as well as several autoimmune phenomena. The autoimmune phenomena range from 
Table 1. Biological agents for the treatment of autoimmune rheumatic diseases.

\begin{tabular}{|c|c|c|c|}
\hline Target & Agent & Structure & Indications \\
\hline $\begin{array}{l}\text { Cytokines } \\
\text { TNFa }\end{array}$ & $\begin{array}{l}\text { Adalimumab } \\
\text { Golimumab } \\
\text { Infliximab } \\
\text { Etanercept } \\
\text { Certolizumab } \\
\text { Peg }\end{array}$ & $\begin{array}{l}\text { - Fully human-TNFa mAb } \\
\text { - Fully human-TNFa mAb } \\
\text { - Chimeric -TNFa mAb } \\
\text { - Soluble TNF receptor IgG Fc fusion } \\
\text { protein } \\
\text { - Humanized Fab' Fragment linked to } \\
\text { pegylated molecule }\end{array}$ & $\begin{array}{l}\text { - } \mathrm{RA}, \mathrm{PsA}, \mathrm{AS}, \mathrm{PsO}, \mathrm{JIA}, \mathrm{CD}, \mathrm{UC} \\
\text { - } \mathrm{RA}, \mathrm{PsA}, \mathrm{PsO}, \mathrm{AS}, \mathrm{UC} \\
\text { - } \mathrm{RA}, \mathrm{PsA}, \mathrm{AS}, \mathrm{PsO}, \mathrm{UC}, \mathrm{CD} \\
\text { - } \mathrm{RA}, \mathrm{PsA}, \mathrm{AS}, \mathrm{PsO}, \mathrm{JIA} \\
\text { - } \mathrm{RA}, \mathrm{PsA}, \mathrm{AS}, \mathrm{PsO}, \mathrm{CD}\end{array}$ \\
\hline IL-1 receptor & Anakinra & Recombinant IL-1 receptor antagonist & RA, CAPS \\
\hline IL-6 receptor & $\begin{array}{l}\text { - Tocilizumab } \\
\text { - Sarilumab } \\
\end{array}$ & Humanized anti IL-6 receptor mAb & RA, JIA, TA \\
\hline IL-12/IL-23 & Ustekinumab & Fully human anti IL-12/IL-23 mAb & $\mathrm{PsA}, \mathrm{PsO}$ \\
\hline $\mathrm{IL}-17$ & Secukinumab & Fully human anti-17A mAb & PsA, AS, PsO \\
\hline $\begin{array}{l}\text { Lymhocyte } \\
\text { - T-cell } \\
\text { CD28 } \\
\text { - B cell } \\
\text { CD20 } \\
\text { BAFF }\end{array}$ & $\begin{array}{l}\text { - Abatacept } \\
\text { - Rituximab } \\
\text { - Belimumab } \\
\end{array}$ & $\begin{array}{l}\text { CTLA-4 IgG Fc fusion protein } \\
\text { Chimeric anti-CD20 mAb } \\
\text { Fully human mAb for solute BAFF }\end{array}$ & $\begin{array}{l}\text { RA, JIA } \\
\text { SLE } \\
\text { SLE }\end{array}$ \\
\hline $\begin{array}{l}\text { Biosimilars } \\
\text { - TNFa } \\
\text { - } \mathrm{CD} 20\end{array}$ & $\begin{array}{l}\text { - Adalimumab } \\
\text { - Etanercept } \\
\text { - Rituximab }\end{array}$ & & \\
\hline
\end{tabular}

AS: Ankylosing Spondylitis; BAFF: B-cell activation factor; CAPS: cryopyrin-associated periodic syndrome; CD: Crohn's disease; CLL: chronic lymphocytic leukaemia; CTLA4: cytotoxic T-lymphocyte antigen 4; Fab: Fragment antigen binding; GPA: granulomatosis with polyangiitis; JIA: juvenile idiopathic arthritis; MPA: microscopic polyangiitis; mAb: monoclonal antibody; NHL : non-Hodgkin lymphoma; PsA: psoriatic arthritis; Pso: psoriasis; RA: rheumatoid arthritis; SLE: systemic lupus erythematosus; TA: temporal arteritis; UC: ulcerative colitis.

an isolated presence of an antibody, mainly antinuclear antibody (ANA), to full-blown autoimmune diseases. ${ }^{7}$

In this review we will discuss the autoimmune phenomena related mainly with the use of the TNFa inhibitors (TNFai), which are the most widely used among biological agents. ${ }^{8,9}$

\section{BIOLOGICAL AGENTS}

Specific biologic agents against cytokines and lymphocytes have been developed and approved for the treatment of ARDs. The most commonly used are the TNFai which include: the monoclonal antibodies (mAb) adalimumab (ADA), infliximab (INF), golimumab (GOL), the soluble TNF receptor IgG Fc fusion protein etanercept (ETN), the pegylated antibody fragment certolizumab (CTZ), ${ }^{10-14}$ and TNFai biosimilars. ${ }^{15,16}$ Other cytokine inhibitors comprise the mAb tocilizumab (TCZ) and sarilumab (SAR), which are IL-6 receptor antagonists. ${ }^{17,18}$ Anakinra is an IL-1 receptor antagonist while, secukinumab is an IL-17A mAb, and ustekinumab an IL-12/IL-23 mAb. ${ }^{10}$ Table 1 depicts the biologic agents used in the treatment of ARD.

\section{AUTOIMMUNE PHENOMENA AND SYSTEMIC DISEASES}

Autoimmune phenomena associated with biological therapies usually manifest during the first months of treatment (1-8 months), but can also manifest after years 


\section{MEDITERRANEAN JOURNAL OF RHEUMATOLOGY

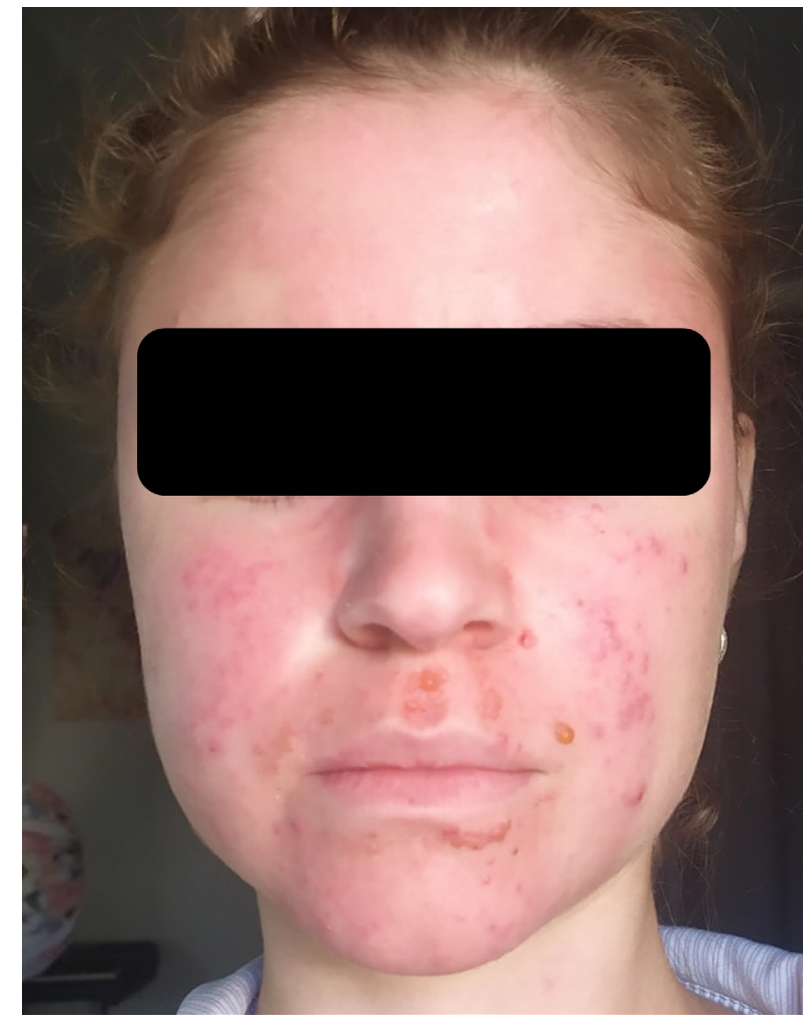

Figure 1. A 26-year-old woman with seropositive rheumatoid arthritis refractory to methotrexate received adalimumab 40mg every 14 days subcutaneously. She responded very well, but 6 months later she developed erythematous eruptions affecting her face in a butterfly distribution and with blister formation.

in a few patients. The autoimmune phenomena and clinical manifestations range from an isolated presence of an antibody, mostly ANA, or double stranded DNA (ds-DNA), to full blown autoimmune diseases, organ specific and systemic. ${ }^{19-21}$

The organ specific diseases include: uveitis, multiple sclerosis (MS) like lesions, myelitis, optic neuritis, interstitial lung disease (ILD) and others. Systemic diseases comprise drug-induced lupus (DIL), systemic vasculitis, antiphospholipid syndrome (APS), inflammatory myopathies, and others. ${ }^{22-26}$ The occurrence of antibodies manifested during the use of biologic agents varies considerably among studies. ANAs have been reported to occur from 40-100\%, ${ }^{20,27}$ dsDNA from $11-62 \%,{ }^{21,25}$ and antiphospholipid antibodies (APLs) between $2-12 \%,{ }^{21,25}$ while other antibodies like Sm, Ro (SSA), La (SSB) have been reported less frequently.22,23 The clinical manifestations of DIL due to TNFai comprise arthritis, photosensitivity, skin manifestations (malar rash, discoid, annular and psoriasiform lesions) (Figure 1), oral ulcers, myalgias, while kidney disease and central nervous system (CNS) involvement are uncommon. However, patients with severe lupus present with a plethora of antibodies such as ds-DNA, Ro (SSA) or La (SSB) and low complement levels. ${ }^{22-26}$

The mechanisms to explain the production of antibodies and DIL development during TNFai are not well understood. However, one hypothesis is that TNFai can induce cell apoptosis, generation of antigenic material, and ultimately antibody formation with lupus manifestations. ${ }^{28}$ Another theory is that TNFai can interfere with Th1/Th2 immune response in which there is a Th1 suppression in favor of Th2 response with the production of IFNa and $\beta$ which can evolve in lupus pathogenesis. ${ }^{7,29,30}$ Another speculation is that a latent infection in patients treated with TNFai may trigger the formation of antibodies and DIL manifestations. ${ }^{7,29,30}$ Regarding the treatment in these patients, TNFai discontinuation is an imperative. Furthermore, local calcineurin inhibitors, with or without small doses of prednisone for skin manifestations are sufficient, and patients respond well until complete resolution. However, even rare, in patients who develop severe lupus manifestations, such as lupus nephritis or CNS manifestations, high doses of prednisone and immunosuppressive drugs are required. ${ }^{22,24,31}$

\section{PARADOXICAL INFLAMMATION}

The most common autoimmune phenomenon related to biological therapies, especially with the use of TNFai is the paradoxical inflammation. This is an intriguing manifestation that can be presented with the same clinical features for which TNFai are used to treat symptoms of RA, PsA, psoriasis, and IBD (inflammatory bowel disease). Thus, the paradoxical inflammation phenomenon can be presented as arthritis, uveitis, psoriasis, colitis, and other manifestations. ${ }^{32-35}$ Among them, the most common manifestation is that of psoriatic skin lesions. ${ }^{36-38}$ The prevalence of psoriatic lesions following TNFai therapy ranges between $0.6-5.3 \%$ in RA patients, approximately 4\% in SpA and 1.6-10\% in IBD (inflammatory bowel disease) patients. ${ }^{32-35,39}$ The regions involved in this paradoxical inflammation are mainly the palmoplantar skin and the scalp, however other regions may be affected. ${ }^{36,37}$ Some investigators argued whether TNFai induced psoriasis is a true manifestation, or is an occult clinical feature which is manifested later on, during the disease course. It is of interest that TNFai biosimilars manifested the same paradoxical inflammation of psoriasis, as reported recently by Pelechas et al. ${ }^{40}$ (Figure 2) Indeed, he described an RA patient who was treated with SB4, an ETN biosimilar, and developed psoriatic skin lesions affecting the palms of the hands, 8 months after SB4 therapy initiation. The mechanisms responsible for this autoimmune phenomenon has not been elucidated. However, it is proposed that TNFai may cause a cytokine shift of TNFa and IFNa. It is known that plasmacytoid 


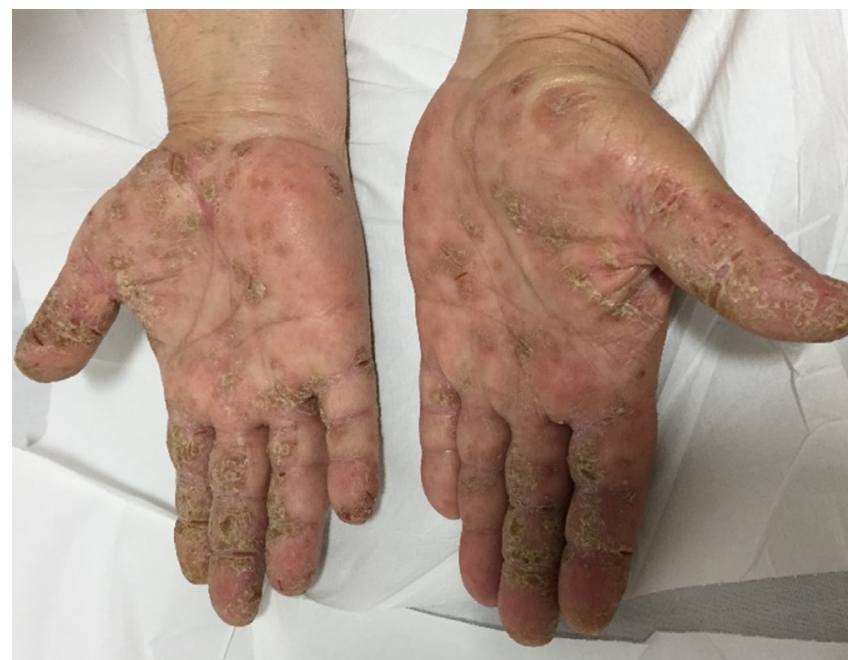

Figure 2. A 62-year-old man with seropositive rheumatoid arthritis refractory to methotrexate and leflunomide was treated with SB4, an etanercept biosimilar 50mg/ week subcutaneously. After 3 months he developed psoriasiform eruptions affecting the palms of the hands.

cells secrete a large amount of IFNa which accumulate in the skin in the early phase of the disease process, and contribute to psoriasis pathogenesis. ${ }^{7}$ On the other side, TNFa prevents the generation of plasmacytoid dendritic cells and downregulates the production of IFNa. Thus, neutralization of TNFa following TNFai increased the production of IFNa by plasmacytoid dendritic cells with the development of skin psoriasis. ${ }^{41-43}$ In addition, other biological therapies can also induce psoriasis. Some case reports and case series of RA and SLE patients treated with rituximab (RTX) developed psoriatic skin lesions. ${ }^{44-46}$ It is postulated that B-cell population depletion from RTX may lead to upregulation of T-cell population and the development of psoriasis. ${ }^{47}$

Another well-documented paradoxical manifestation due to TNFai is granuloma annulare (GA) formation. Davos et al. describes the first case of GA development in a patient with PSA treated with INF. ${ }^{48}$ Subsequently, 9 cases of well documented GA have been reported by Voulgari et al. in RA patients, ${ }^{49}$ while 2 other cases have been described using secukinumab for PsA and psoriasis, respectively. ${ }^{50,51}$ Furthermore, a new case of GA in RA patient treated with tocilizumab has been described recently. ${ }^{52}$ (Figure 3 ) The postulated mechanisms underlying this paradoxical manifestation propose that cytokine inhibitors may cause T-cell upregulation with subsequent macrophage activation leading to granuloma formation. ${ }^{49-52}$ Finally, many other autoimmune skin manifestations following TNFai have been described such as: erythema multiforme, pustular folliculitis, skin vasculitis, vitiligo, and others. ${ }^{38,53}$

As far as it concerns the treatment, cytokine inhibitors

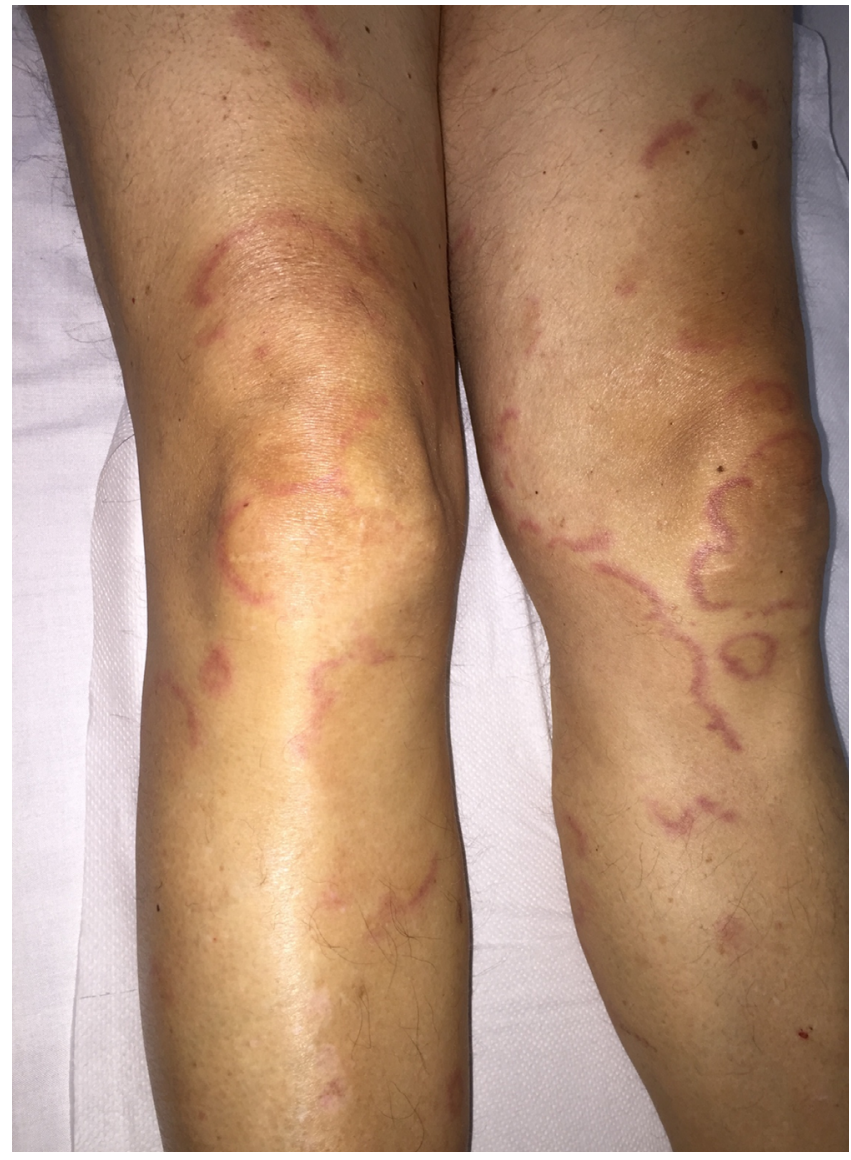

Figure 3. A 65-year-old man with seropositive rheumatoid arthritis refractory to methotrexate and infliximab. He was treated with tocilizumab 162mg/week subcutaneously. He responded very well to the above treatment but eight months later he developed polycyclic skin rashes affecting the lower extremities. The histological picture was compatible with granuloma annulare.

discontinuation may be sufficient in mild cases, however topical steroids and small doses of prednisone may be required in same cases. Usually, the skin manifestations subside with complete resolution after 2 months of biological agent's discontinuation (Figures 4 and 5).

\section{NEUROLOGICAL MANIFESTATIONS (NM)}

Neurological manifestations (NM) in patients receiving biologic agents have been described in case reports, case series, cross sectional and prospective observational studies from institutions and registries. Demyelinating disorders (DD), MS-like lesions, optic neuritis, myelitis, peripheral neuropathies, and others have been described in post-marketing surveillance mainly during TNFai and RTX. ${ }^{54-62}$ The prevalence range from $0.05-0.2 \% .{ }^{25}$ However, in one prospective study the estimated prevalence was 4\%. ${ }^{63}$ Indeed, in this study 36 patients with 


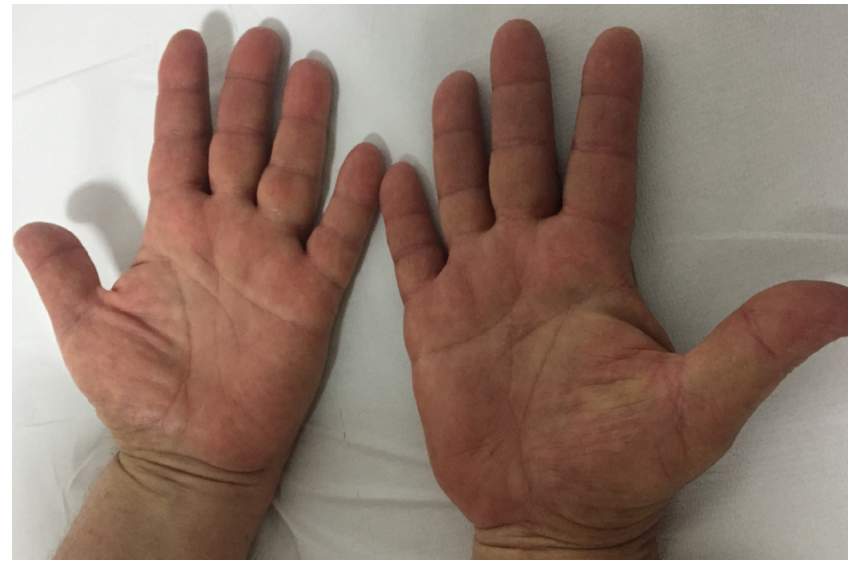

Figure 4. The same patient as in Figure 2, two months later after discontinuation of SB4 receiving small doses of prednisone. Note the complete resolution of the psoriasiform skin rashes.

RA and 41 with SpA (24 PsA, 17 AS) who were eligible for TNFai therapy were investigated. Before treatment, all patients had a complete physical and neurological evaluation, and all had brain and cervical spine magnetic resonance imaging (MRI) and neurophysiological studies. Two patients without any objective clinical manifestation presented in their MRI findings compatible with MSlike lesions, and did not receive TNFai therapy. These patients can be classified as having radiological isolated syndrome (RIS), which is considered a preclinical finding of MS. Finally, a total of 75 patients received TNFai therapy. During follow-up (16-25 months) 3 patients developed NM. A patient with PsA who switched from ETN to INF developed clinical and imaging features of MS-like lesions after 8 months of INF therapy. One of the patients with RA treated with ADA, 8 months later developed optic neuritis, while another patient with AS and Crohn's disease after 25 months of INF treatment developed peripheral sensorimotor polyneuropathy. ${ }^{63}$ All patients discontinued ant-TNFa therapy, and the clinical features disappeared two months later. Kopp et al. in a prospective observational study in patients with RA and SpA receiving TNFai, found an increased risk of NM in SpA patients, as compared to controls without receiving TNFai. On the other hand, they found no consistent and significant risk of NM after TNFai in RA patients. They concluded that the risk of NM following TNFai is disease-dependent and not agent-dependent. ${ }^{64}$ However, new autoimmune NM have been described in RA patients. Indeed, two patients one receiving ETN 65 and the other ADA $^{66}$ developed myasthenia Gravis. All the above indicate that NM following TNFai therapy are drug-dependent and not disease-dependent. This means that it is a class effect phenomenon. ${ }^{67}$ The mech-

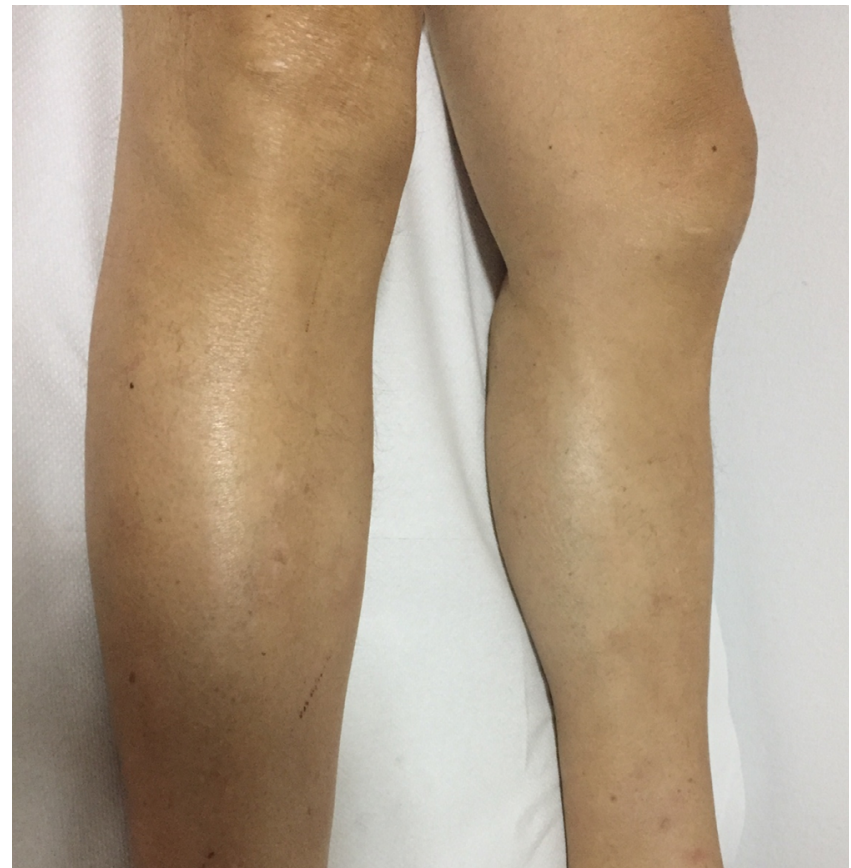

Figure 5. The same patient as in Figure 3, three months later after tocilizumab discontinuation receiving prednisone $10 \mathrm{mg} /$ day. Note the complete resolution of granuloma annulare eruptions.

anisms responsible for the development of $\mathrm{NM}$ after TNFai are unclear. However, some hypothesis propose that 1) TNFai increase the autoreactive T-cells in the peripheral blood, which can penetrate into CNS causing MS-like lesions; 2) TNFai may cause downregulation of TNF receptors 2 (TNFR2) in the brain, necessary for the proliferation of oligodendrocytes and damage repair; 3) downregulation of $\mathrm{IL}-10$ and upregulation of $\mathrm{IL}-12$ and IFNy responsible for DD process; and 4) finally, a latent infection may be critical to initiate a DD process. ${ }^{68}$

In addition, treatment with biologic agents induced another DD known as progressive multifocal leukoencephalopathy (PML). This is a rare, but sometimes fatal DD of CNS, caused by the reactivation of John Cunningham virus (JCV). The incidence of PML development in patients TNFai is very low. Some case reports have been published in this direction. ${ }^{69}$ However, efalizumab, a mAb against leucocyte function activation protein 1 (LFA1), that had been used for the treatment of plaque psoriasis since 2003, has been reported to cause PML. ${ }^{70,71}$ Thus, the authorities withdraw the drug from the market in 2009. On the other hand, RTX has been also associated with PML development. PML is a well-described pathology in oncology patients receiving RTX for non-Hodgkin lymphoma and chronic lymphocytic leukaemia. ${ }^{60,61}$ In the rheumatology setting, PML has been described to occur initially in patients with SLE and later on in RA patients 
and in patients with vasculitis receiving RTX. Between 2006-2015 approximately 351,396 RA patients have been treated with RTX and 9 cases with PML were identified giving a rate of 2.56/100,000, while only 2 cases of PML in patients with vasculitis have been reported since 2015. 60,61 Treatment requires discontinuation of RTX, and steroids with or without other immunosuppressive drugs.

\section{OTHER AUTOIMMUNE PHENOMENA}

Other autoimmune diseases, mainly organ specific following biologic agents' therapy have been rarely reported. Inflammatory myopathies, ILD, inflammatory ocular diseases, IBD, sarcoidosis, and others are among them. ${ }^{25,72-75}$

\section{CONCLUSIONS}

The use of biologic therapies has revolutionized the treatment of ARD. However, the use of these agents may affect the normal immune function and its response, leading to the development of many autoimmune phenomena and diseases. These phenomena range from isolated discovery of an autoantibody, to full-blown autoimmune diseases, organ specific, and systemic. This review has been carried out in order to underline the multitude of the potential adverse manifestations from the use of biologic agents. Early recognition of the specific types of autoimmune phenomena is an imperative for physicians. They must have the opportunity to diagnose and treat them appropriately early on their development avoiding misinterpretations and misdiagnoses that may exhaust patients with unnecessary laboratory tests and visits to different specialists. Thus, close follow-up and monitoring is mandatory.

\section{TAKE-HOME NOTES}

The use of biologic agents has revolutionized the treatment of ARD. However, their use may alter the immune system function and its normal responses. A large number of clinical and laboratory autoimmune phenomena have been emerged ranging from an asymptomatic immunological alteration to organ specific and systemic diseases.

A careful and minute past medical and family history of pre-existing clinical features suggestive of an underlying autoimmune disease, followed by a detailed clinical and immunological evaluation before the initiation of biological therapy is mandatory.

Recognition of the specific types of autoimmune phenomena and diseases will allow physicians to have an accurate diagnosis and treatment plan. Thus, physicians dealing with patients treated with biological therapies should be aware of the possible development of several autoimmune phenomena, therefore close follow-up and monitoring is essential.

Treatment requires cessation of biologic agents, which probably may be sufficient in mild cases, but in cases of systemic manifestations, small or high doses of prednisone with or without immunosuppressive drugs are required. Usually, the prognosis and outcome are good.

\section{FUNDING}

This research did not receive any specific grant from funding agencies in the public, commercial, or not-forprofit sectors.

\section{AUTHOR CONTRIBUTIONS}

All authors have made substantial contributions to the current manuscript and approved the final version fulfilling all the four criteria proposed be the ICMJE. EP: drafting; EK: drafting; TEM: drafting; PW: revision; AAD: conception of the work, revision.

\section{ACKNOWLEDGEMENTS}

We would like to thank Areti Fili for the excellent secretarial assistance.

\section{CONFLICT OF INTEREST}

The authors declare no conflict of interest.

\section{REFERENCES}

1. Drayton DL, Liao S, Mounzer RH, Ruddle NH. Lymphoid organ development: from ontogeny to neogenesis. Nat Immunol 2006; 7(4):344-53.

2. Davidson A, Diamond B. Autoimmune diseases. N Engl J Med 2001;345(5):340-50.

3. Rosman Z, Shoenfeld Y, Zandman-Goddard G. Biologic therapy for autoimmune diseases: an update. BMC Med 2013;11:88.

4. Burmester GR, Feist E, Dorner T. Emerging cell and cytokine targets in rheumatoid arthritis. Nat Rev Rheumatol 2014;10(2):77-88.

5. Pichler WJ. Adverse side-effects to biological agents. Allergy 2006;61(8):912-20.

6. Boyman O, Comte D, Spertini F. Adverse reactions to biologic agents and their medical management. Nat Rev Rheumatol 2014;10(10):612-27

7. Her M, Kavanaugh A. Alterations in immune function with biologic therapies for autoimmune disease. J Allergy Clin Immunol 2016;137(1):19-27.

8. Ramos-Casals, Brito-Zeron P, Soto MJ, Cuadrado MJ, Khamashta MA. Autoimmune diseases induced by TNF-targeted therapies. Best Pract Res Clin Rheumatol 2008;22(5):847-61.

9. Gasparyan AY, Ayvazyan L, Blackmore H, Kitas GD. Writing a narrative biomedical review: considerations for authors, peer reviewers, and editors. Rheumatol Int 2011;31(11):1409-17.

10. Sfikakis PP, Bournia VK, Sidiropoulos P, Boumpas DT, Drosos $A A$, Kitas GD, et al. Biologic treatment for rheumatic disease: real-world big data analysis from the Greek country-wide prescription database. Clin Exp Rheumatol 2017;35(4):579-85.

11. Flouri I, Markatseli TE, Voulgari PV, Boki KA, Papadopoulos I, Settas L, et al. Comparative effectiveness and survival of infliximab, adalimumab, and etanercept for rheumatoid arthritis patients in the Hellenic Registry of Biologics: low rates of remission and 5-year drug survival. Semin Arthritis Rheum 2014;43(4):447-57.

12. Voulgari PV, Drosos AA. Adalimumab for rheumatoid arthritis. Expert Opin Biol Ther 2006;6(12)1349-60.

13. Papagoras Ch, Voulgari PV, Drosos AA. Golimumab, the newest TNF-a blocker, comes of age. Clin Exp Rheumatol 2015;33(4):5707 . 
14. Markatseli TE, Papagoras C, Nikoli A, Voulgari PV, Drosos AA. Certolizumab for rheumatoid arthritis. Clin Exp Rheumato 2014;32(3):415-23.

15. Pelechas E, Voulgari PV, Drosos AA. ABP 501 for the treatment of rheumatoid arthritis. Expert Opin Biol Ther 2018;18(3):317-22.

16. Pelechas E, Drosos AA. Etanercept biosimilar SB-4. Expert Opin Biol Ther 2019;19(3):173-9.

17. Markatseli TE, Theodoridou A, Zakalka M, Koukli E, Trantafyllidou E, Tsalavos S, et al. Persistence and adherence during the first six months of tocilizumab treatment among rheumatoid arthritis patients in routine clinical practice in Greece. Results from the single arm REMISSION II Study (NCT01649817). Mediterr J Rheumatol 2019;30(3):177-85.

18. Pelechas E, Voulgari PV, Drosos AA. Clinical evaluation of the safety, efficacy and tolerability of sarilumab in the treatment of moderate to severe rheumatoid arthritis. Ther Clin Risk Manag 2019;15:1073-79.

19. De Rycke L, Kruithof E, Van Damme N, Hoffman IEA, van den Bossche N, Bosch F, et al. Antinuclear antibodies following infliximab treatment in patients with rheumatoid arthritis or spondylarthropathy. Arthritis Rheum 2003;48(4).

20. Charles PJ, Smeenk RJ, De Jong J, Feldmann M, Maini RN Assessment of antibodies to double-stranded DNA induced in rheumatoid arthritis patients following treatment with infliximab a monoclonal antibody to tumor necrosis factor alpha: findings in open-label and randomized placebo-controlled trials. Arthritis Rheum 2000;43(11):2383-90.

21. Eriksson C, Engstrand S, Sundqvist KG, Rantapaa-Dahlqvist S. Autoantibody formation in patients with rheumatoid arthritis treated with anti-TNFa. Ann Rheum Dis 2005;64:403-7.

22. De Bandt M, Sibilia J, Le Loet X, Prouzeau S, Fautrel B, Marcelli $C$, et al. Systemic lupus erythematosus induced by anti-tumour necrosis factor alpha therapy: a French national survey. Arthritis Res Ther 2005;7(3):R545-R551.

23. Costa MF, Said NR, Zimmermann B. Drug-induced lupus due to anti-tumor necrosis factor alpha agents. Semin Arthritis Rheum 2008;37(6):381-7.

24. Williams EL, Gadola S, Edwards CJ. Anti-TNF-induced lupus. Rheumatology (Oxford) 2009;48(7):716-20

25. Ramos-Casals M, Perez-Alvarez R, Diaz Lagares C, Cuadrado MJ, Khamashta MA. Autoimmune diseases induced by biological agents: a double-edged sword? Autoimmun Rev 2010;9(3):18893.

26. Shovman O, Tamar S, Amital H, Watad A, Shoenfeld Y. Diverse patterns of anti-TNF-a induced lupus: case series and review of the literature. Clin Rheumatol 2018;37:563-8

27. Vaz JLP, Andrade CAF, Pereira AC, Martins Md FM, Levy RA. Systematic review of infliximab-induced autoantibodies and systemic lupus erythematosus. Rev Bras Reumatol 2013;53(4):358-64.

28. D'Auria F, Rovere-Querini P, Giazzon M, Ajello P, Baldissera E, Manfredi AA, et al. Accumulation of plasma nucleosomes upon treatment with anti-tumour necrosis factor-a antibodies. J Intern Med 2004;255(3):409-18.

29. Wahren-Herlenius M, Dorner T. Immunopathogenic mechanisms of systemic autoimmune disease. Lancet 2013;382(9894):819-31.

30. Chang C, Gershwin ME. Drugs and autoimmunity - a contemporary review and mechanistic approach. J Autoimmun 2010;34(3):J26675.

31. Chang C, Gershwin ME. Drug-induced lupus erythematosus: incidence, management and prevention. Drug Saf 2011;34(5):357-74

32. Reilly E, Edwards, C, Mackay K. Anti-TNF therapy induced arthritis in patients with inflammatory bowel disease. Rheumatology (Oxford) 2015;54(suppl 1):i94

33. Cobo-lbáñez, del Carmen Ordóñez M, Muñoz-Fernández S, Madero-Prado R, Martín-Mola E. Do TNF-blockers reduce or induce uveitis? Rheumatology (Oxford) 2008;47(5):731-2.

34. Korzenik J, Larsen MD, Nielsen F, Kjeldsen J, Nørgård BM. Increased risk of developing Crohn's disease or ulcerative colitis in 17018 patients while under treatment with anti-TNFa agents, par- ticularly etanercept, for autoimmune diseases other than inflammatory bowel disease. Aliment Pharmacol Ther 2019;50(3):2890294.

35. Fiorino G, Danese S, Pariente B, Allez M. Paradoxical immune-mediated inflammation in inflammatory bowel disease patients receiving anti-TNF-a agents. Autoimmun Rev 2014;13(1):15-9.

36. Sfikakis PP, Iliopoulos A, Elezoglou A, Kittas C, Stratigos A. Psoriasis induced by anti-tumor necrosis factor therapy: a paradoxical adverse reaction. Arthritis Rheum 2005;52(8):2513-8.

37. De Gannes GC, Ghoreishi M, Pope J, Russell A, Bell D, Adams $S$, et al. Psoriasis and pustular dermatitis triggered by TNF-a inhibitors in patients with rheumatologic conditions. Arch Dermato 2007;143(2):223-31

38. Exarchou SA, Voulgari PV, Markatseli TE, Zioga A, Drosos AA. Immune-mediated skin lesions in patients treated with anti-tumour necrosis factor alpha inhibitors. Scand J Rheumatol 2009;38(5):328-31.

39. Fréling E, Baumann C, Cuny JF, Bigard MA, Schmutz JL, Bardaud $A$, et al. Cumulative incidence of, risk factor for, and outcome of dermatological complications of anti-TNF therapy in inflammatory bowel disease: a 14-year experience. Am J Gastroneterol 2015;11(8):1186-96.

40. Pelechas E, Papoudou-Bai A, Voulgari PV, Drosos AA. Cutaneous autoimmune phenomena of the anti-TNFa biosimilars. Casebased Review. Curr Rheumatol Rev 2021;17(2):267-70.

41. Nestle FO, Conrad C, Tun-Kyi A, Homey B, Gombert M, Boyman $\mathrm{O}$, et al. Plasmacytoid predendritic cells initiate psoriasis through interferon-alpha production. J Exp Med 2005:202(1):135-43.

42. Palucka AK, Blanck JP, Bennett L, Pascual V, Banchereau J. Cross-regulation of TNF and IFN-alpha in autoimmune diseases. Proc Natl Acad Sci USA 2005;102(9):3372-7.

43. Seneschal J, Milpied B, Vergier B, Lepreux S, Schaeverbeke T, Taïeb A. Cytokine imbalance with increased production of interferon-alpha in psoriasiform eruptions associated with antitumour necrosis factor-alpha treatments. Br J Dermatol 2009;161(5):1081-8.

44. Dass S, Vital EM, Emery P. Development of psoriasis after B cell depletion with rituximab. Arthritis Rheum 2007:56(8):2715-8.

45. Mielke F, Schneider-Obermeyer J, Dörner T. Onset of psoriasis with psoriatic arthropathy during rituximab treatment of non-Hodgkin lymphoma. Ann Rheum Dis 2008;67(7):1056-7

46. Markatseli TE, Kaltsonoudis ES, Voulgari PV, Zioga A, Drosos AA. Induction of psoriatic skin lesions in a patient with rheumatoid arthritis treated with rituximab. Clin Exp Rheumatol 2009;27(6):9968.

47. Looney RJ, Anolik J, Sanz I. B cells as therapeutic targets for rheumatic diseases. Curr Opin Rheumatol 2004;16(3):180-5.

48. Devos SA, van Den Bossche N, de Vos M, Naeyaert JM. Adverse skin reactions to anti-TNF-alpha monoclonal antibody therapy. Dermatology 2003;206(4):388-90

49. Voulgari PV, Markatseli TE, Exarchou SA, Zioga A, Drosos AA Granuloma annulare induced by anti-tumour necrosis factor therapy. Ann Rheum Dis 2008;67(4):567-70. Doi: 10.1136/ ard.2007.075663

50. Bonomo L, Ghoneim S, Levitt J. A case of granuloma annulare associated with secukinumab use. Case Rep Dermatol Med 2017:5918708.

51. Clark ML, Tobin CA, Sutton A, Missall TA. Granuloma annulare in the setting of secukinumab. Case Rep Dermatol Med 2018:5175319.

52. Pelechas E, Papoudou-Bai A, Voulgari PV, Drosos AA. Granuloma annulare development in a patient with rheumatoid arthritis treated with tocilizumab: case-based review. Rheumatol Int 2019;39(2):353-7

53. Hawryluk EB, Linskey KR, Duncan LM, Nazarian RM. Broad range of adverse cutaneous eruptions in patients on TNF-alpha antagonists. J Cutan Pathol 2012;39(5):481-92.

54. Perez-Alvarez R, Pérez-de-Lis M, Ramos-Casals M. Biologics-induced autoimmune diseases. Curr Opin Rheumatol 2013;25(1):5664

55. Bosch X, Saiz A, Ramos-Casals M. Monoclonal antibody therapy-associated neurologic disorders. Nat Rev Neurol 2011;7:165- 
72.

56. Fernandez-Espartero MC, Perez-Zafrilla B, Nananjo A, Esteban C, Ortiz AM, Gomez-Reino JJ, et al. Demyelinating disease in patients treated with TNF antagonists in rheumatology: data from BIOBADASER, a pharmacovigilance database, and a systematic review. Semin Arthritis Rheum 2011;40(4):330-7.

57. Andreadou E, Kemanetzoglou E, Brokalaki Ch, Evangelopoulos ME, Kilidireas C, Rombos A, et al. Demyelinating disease following anti-TNFa treatment: a causal or coincidental association? Report of four cases and review of the literature. Case Rep Neurol Med 2013;2013:671935.

58. Faillace C, de Almeida JRM, de Carvalho JF. Optic neuritis after infliximab therapy. Rheumatol Int 2013;33:1101-3.

59. Molloy ES, Calabrese LH. Progressive multifocal leukoencephalopathy associated with immunosuppressive therapy in rheumatic diseases: evolving role of biologic therapies. Arthritis Rheum 2012;64(9):3043-51.

60. Lin EJ, Reddy S, Shah W, Wu JJ. A review of neurologic complications of biologic therapy in plaque psoriasis. Cutis 2018;101(1):5760.

61. Berger JR, Malik V, Lacey S, Brunetta P, Lehane PB. Progressive multifocal leukoencephalopathy in rituximab-treated rheumatic diseases: a rare event. J Neurovirol 2018:24(3):323-31.

62. Islam MM, Poly TN, Yang HC, Wu CC, Li YC. Increase risk of multiple sclerosis in patients with psoriasis disease: an Evidence of observational studies. Neuroepidemiology 2019;52(3-4):152-60.

63. Kaltsonoudis E, Zikou AK, Voulgari PV, Konitsiotis S, Argyropoulou $\mathrm{MI}$, Drosos AA. Neurological adverse events in patients receiving anti-TNF therapy: aprospective imaging and electrophysiological study. Arthritis Res Ther 2014;16(3):R125.

64. Kopp TI, Delcoigne B, Arkema EV, Jacobsen RK, Magyari M, Ibfelt $\mathrm{EH}$, et al. Risk of neuroinflammatory events in arthritis patients treated with tumour necrosis factor alpha inhibitors: a collaborative population-based cohort study from Denmark and Sweden. Ann Rheum Dis 2020;79(5):566-72.

65. Fee DB, Kasarskis EJ. Myasthenia gravis associated with etanercept therapy. Muscle Nerve 2009;39(6):866-70.

66. Pelechas E, Memi T, Markatseli TE, Voulgari PV, Drosos AA. Adalimumab-induced myasthenia gravis: case-based review. Rheumatol Int 2020;40(11):1891-4.

67. Kaltsonoudis E, Pelechas E, Voulgari PV, Drosos AA. Neuroinflammatory events after anti-TNFa therapy. Ann Rheum Dis May 2020; annrheumdis-2020-217723.

68. Kaltsonoudis E, Voulgari PV, Konitsiotis S, Drosos AA. Demyelination and other neurological adverse events after anti-TNF therapy. Autoimmun Rev 2014;13(1):54-8.

69. Tavazzi E, Ferrante P, Khalili K. Progressive multifocal leukoencephalopathy: an unexpected complication of modern therapeutic monoclonal antibody therapies. Clin Microbiol Infect 2011;17(12):1776-80.

70. Kothary N, Diak IL, Brinker A, Bezabeh S, Avigan M, Pan GD. Progressive multifocal leukoencephalopathy associated with efalizumab use in psoriasis patients. J Am Acad Dermatol 2011;65(3):546-51.

71. Korman BD, Tyler KL, Korman NJ. Progressive multifocal leukoencephalopathy, efalizumab, and immunosuppression: a cautionary tale for dermatologists. Arch Dermatol 2009;145(8):937-42.

72. Perez-Alvarez R, Perez-de-Lis M, Diaz-Lagares C, Pego-Reigosa JM, Retamozo S, Bove A, et al. Interstitial lung disease induced or exacerbated by TNF-targeted therapies: analysis of 122 cases. Semin Arthritis Rheum 2011;41(2):256-64.

73. Scrivo R, Spadaro A, Spinelli FR, Valesini G. Uveitis following the us of tumor necrosis factor alpha inhibitors: comment on the article by Lim et al. Arthritis Rheum 2008;58(5):1555-6.

74. Song $\mathrm{IH}$, Appel H, Haibel H, Loddenkemper C, Braun J, Sieper J, et al. New onset of Crohn's disease during treatment of active ankylosing spondylitis with etanercept. J Rheumatol 2008;35(3):5326.

75. Daien Cl, Monnier A, Claudepierre P, Constantin A, Eschard JP,
Houvenagel E, et al. Sarcoid-like granulomatosis in patients treated with tumor necrosis factor blockers: 10 cases. Rheumatology (Oxford) 2009;48(8):883-6. 